\title{
CHEMICAL STRUCTURE OPTIMIZATION OF LUPEOL AS ER-A AND HER2 INHIBITOR
}

\section{MOHAMMAD RIZKI FADHIL PRATAMA ${ }^{1 *}$, SUTOMO S}

${ }^{1}$ Department of Pharmacy, Faculty of Health Sciences, Muhammadiyah University of Palangkaraya, Palangka Raya, Central Borneo, Indonesia. ${ }^{2}$ Pharmacy Study Programme, Faculty of Mathematics and Natural Sciences, Universitas Lambung Mangkurat, Banjarmasin, South Borneo, Indonesia. Email: m.rizkifadhil@umpalangkaraya.ac.id

Received: 11 December 2017, Revised and Accepted: 14 March 2018

ABSTRACT

Objectives: Lupeol, a triterpenoid isolated from Kasturi (Mangifera casturi) fruit has been known for having several pharmacological activities, including anticancer properties. Lupeol showed antiproliferative activity toward many cancer cells line including breast cancer. Lupeol showed promising potency as both ER- $\alpha$ and HER2 inhibitors, although still lower than known ER- $\alpha$ and HER2 Inhibitors. Chemical structure optimization of lupeol was predicted could increase the affinity of lupeol derivatives against ER- $\alpha$ and HER2. This study aims to determine lupeol derivative with the highest affinity against ER- $\alpha$ and HER2.

Methods: All ligands were sketched and optimized using Gaussian 03W with Hartree-Fock method basis set 3-21G. Molecular docking was performed using Autodock 4.2.6 on several modified chemical structure of lupeol against active site of ER- $\alpha$ and HER2. The main parameter used was the free energy of binding and inhibition constants as affinity marker.

Results: The docking results show that lupeol derivative with an amine group (Lupeol-2) and ethyl group (Lupeol-4) at position C3 provide the highest affinity with the free energy of binding and dissociation constant $-12.24 \mathrm{kcal} / \mathrm{mol}$ and $1.07 \mathrm{nM}$ for ER- $\alpha$ also $-9.63 \mathrm{kcal} / \mathrm{mol}$ and $86.94 \mathrm{nM}$ for HER2, respectively. Interestingly, although lupeol derivatives showed higher affinity toward ER- $\alpha$, their amino acid residues were closer to the interaction on HER2.

Conclusion: These results predict that lupeol have greater potential to be developed as a HER2 inhibitor. Further, derivate lupeol-4 should be potential to be developed as HER2-positive breast cancer therapy.

Keywords: Breast cancer, Docking, ER- $\alpha$, HER2, Lupeol.

(C) 2018 The Authors. Published by Innovare Academic Sciences Pvt Ltd. This is an open access article under the CC BY license (http://creativecommons. org/licenses/by/4. 0/) DOI: http://dx.doi.org/10.22159/ajpcr.2018.v11i6.24226

\section{INTRODUCTION}

The search for various pharmacological activities of the Kasturi, especially from the fruit, has shown a very promising development. Not only as an antioxidant [1], the kasturi fruit extract also exhibits immunomodulatory [2], anti-inflammatory [3], even antileukemia properties [4]. Various secondary metabolite compounds have been isolated from Kasturi fruit, including gallic acid, methyl gallate, 2,3-dihydroxybenzoic acid, dihydroxyquercetin, glucogallin, $\beta$-sitosterol, and lupeol [4-6].

Lupeol, a triterpenoid compound isolated from the fruit of Kasturi is known to have anti-inflammatory and anticancer activity. Several studies have demonstrated lupeol anticancer activity in some cancer cells, such as blood cancer [7], lung cancer, cervical cancer, skin cancer, and breast cancer [8]. Lupeol especially showed good anticancer activity in breast cancer for both ER- $\alpha$-positive and HER2-positive breast cancer. Lupeol anticancer activity is predicted to be associated with antiproliferation and induced apoptotic effects of cancer cells [9].

Despite showing potential for therapy both types of breast cancer, lupeol anticancer potency is still lower than the currently available treatment options for each type of breast cancer [10]. Tamoxifen, a prodrug of 4-hydroxytamoxifen is currently one of the most common options for the treatment of ER- $\alpha$-positive breast cancer [11], while various tyrosine-kinase inhibitors are also being developed as a HER2-positive breast cancer treatment, one of them is TAK-285 [12]. One of the ways to increase lupeol affinity with both ER- $\alpha$ and HER2 receptors is to optimize the lupeol chemical structure by modifying its pharmacophore [13]. Determination of the main pharmacophore with the greatest influence on the affinity of a ligand on the receptor can be done by removing or modifying each pharmacophore of the ligand one by one [14]. The modified ligands were reexamined by the molecular docking method to see the affinity change of the modified ligand $[15,16]$.

This study aims to find the best modification of chemical structure in pharmacophore from lupeol as ER- $\alpha$ and HER2 inhibitor which gives the highest affinity. The modified results were then re-tested and compared with known ER- $\alpha$ and HER2 inhibitors to determine the lupeol potential for development as a therapy for ER- $\alpha$-positive and HER2-positive breast cancer.

\section{METHODS}

\section{Preparation of ligands}

The ligand used was lupeol and derivatives as shown in Table 1. Modification of lupeol derivatives was performed on C3 (Lupeol-1 to Lupeol-10) and C20 atoms (Lupeol-11). The two-dimension structure of lupeol and derivatives is shown in Fig. 1.

Structures of lupeol and derivatives were sketched using GaussView 3.08 Software from Gaussian, Inc. All structures were geometry optimized by Hartree-Fock method basis set 3-21G with Gaussian 03 W software from Gaussian, Inc. Geometry optimization provided an ideal conformation of following compounds that approaching conformation of these compounds in nature [17]. Optimized structures format changed from.log to.pdb using Open Babel 2.4.1 software [18]. Docking program used in this study was Autodock 4.2.6 from The Scripps Research Institute. All ligands then are given the charge and set torque using software AutoDockTools 1.5.6 [19]. 


\section{Preparation of receptors}

The molecular structure of ER- $\alpha$ in complexes with 4-hydroxytamoxifen (protein data bank [PDB] ID 3ERT) and HER2 in complexes with TAK285 (PDB ID 3PP0) was obtained from website of PDB http://www. rscb.org. The receptors were downloaded in.pdb format and then removed the unused portion, added the non-polar hydrogen group, given the charge, and set the grid box size and coordinate using software AutoDockTools 1.5.6 [19]. The used structure of ER- $\alpha$ is the active site which binds with 4-hydroxytamoxifen as a cocrystal ligand. 4-hydroxytamoxifen or afimoxifene is a potent ER- $\alpha$ inhibitor that can slowing cell proliferation rate of cancer cells in ER- $\alpha$-positive breast cancer [20]. While the used structure of HER2 is a tyrosine-kinase domain which binds with TAK-285, a potent small molecule tyrosine kinase inhibitor of HER2 as a cocrystal ligand [21]. Tyrosine-kinase domain was chosen because the active site is known and already used for the development of HER2 inhibitors [22].

\section{Validation of docking process}

The method used for docking validation was redocking the cocrystal ligand into the active site of each receptor. The parameters observed in validation are root-mean-square deviation (RMSD) of each cocrystal ligands at the selected binding site. RMSD scores describe the average difference in position of the atoms of the redocking ligand with the crystallographic results. Docking programs are preferred to predict results from experimental poses with RMSD no more than 2 Å. Smaller RMSD indicates that position of redocking results ligand was closer to crystallography results ligand [23,24].

\section{Molecular docking}

Molecular docking is done using software AutoDock 4.2.6 from The Scripps Research Institute. Docking for all test ligand performed in same way as validation process with similar size and position of grid box [24]. The main parameter used in docking process was the free energy of binding $(\Delta \mathrm{G})$, dissociation constant $\left(\mathrm{K}_{\mathrm{i}}\right)$, amino acid residues and number of hydrogen bonds [25]. Ligand affinity to the receptor in docking method is determined by $\Delta \mathrm{G}$ and $\mathrm{K}_{\mathrm{i}}$ scores. The more negative $\Delta \mathrm{G}$ and lower $\mathrm{K}_{\mathrm{i}}$ indicated higher ligand affinity toward active site of the used receptor [26]. Test ligand with the highest affinity was compared with validation result of cocrystal ligand to determine the potency of test ligand as each receptors inhibitor [17]. The amino acid residues of selected test ligand for each receptor then compared with amino acid residues of cocrystal ligand to assess the similarity of interaction between test and cocrystal ligand. The more similar amino acid residues are indicating a higher probability that the test ligand will have similar activity with the cocrystal ligand [27].

\section{RESULTS AND DISCUSSION}

Validation was performed on the active site of each receptor using cocrystal ligand as references for determining the size and coordinates of each grid box. The redocking results are shown in Fig. 2.

In Fig. 2 can be seen that the position of each redocking ligand almost overlapped with the crystallographic ligand position both on ER- $\alpha$ and HER2 receptors. The RMSD scores of each receptor also $<2 \AA$, indicate that both 3ERT and 3PP0 receptors are valid for use in the docking process [23]. Other parameters observed in the validation of receptors such as $\Delta \mathrm{G}, \mathrm{K}_{\mathrm{i}}$, amino acid residues, and a number of hydrogen bonds including the size and coordinate of the grid box are shown in Table 2.

Docking was performed using Autodock 4.2.6 at the active site of ER- $\alpha$, and HER2 receptors with 100 genetic algorithms run to improve the accuracy of docking result [19]. For each test ligand, one poses with the most negative $\Delta \mathrm{G}$ and the lowest $\mathrm{K}_{\mathrm{i}}$ was selected as representatives of test ligand [17]. The docking results data of all test ligands to both receptors were compared each other as shown in Tables 3-8.

All test ligands in both ER- $\alpha$ and HER2 receptors show negative $\Delta \mathrm{G}$ scores, indicating that the interaction between ER- $\alpha$ and HER2 receptors with all test ligands will occur spontaneously [24]. In ER- $\alpha$
Table 1: Lupeol derivatives including modified functional groups

\begin{tabular}{lll}
\hline Compounds & $\mathbf{R}_{\mathbf{1}}$ & $\mathbf{R}_{\mathbf{2}}$ \\
\hline Lupeol (L-0) & $-\mathrm{OH}$ & $-\mathrm{CH}_{2}$ \\
Lupeol derivative 1 (L-1) & $-\mathrm{CH}_{3}$ & $-\mathrm{CH}_{2}$ \\
Lupeol derivative 2 (L-2) & $-\mathrm{NH}_{2}$ & $-\mathrm{CH}_{2}$ \\
Lupeol derivative 3 (L-3) & $-\mathrm{OCH}_{3}$ & $-\mathrm{CH}_{2}$ \\
Lupeol derivative 4 (L-4) & $-\mathrm{CH}_{2} \mathrm{CH}_{3}$ & $-\mathrm{CH}_{2}$ \\
Lupeol derivative 5 (L-5) & $-\mathrm{NHCH}_{3}$ & $-\mathrm{CH}_{2}$ \\
Lupeol derivative 6 (L-6) & $-\mathrm{CH}\left(\mathrm{CH}_{3}\right)_{2}$ & $-\mathrm{CH}_{2}$ \\
Lupeol derivative 7 (L-7) & $-\mathrm{N}\left(\mathrm{CH}_{3}\right)_{2}$ & $-\mathrm{CH}_{2}$ \\
Lupeol derivative 8 (L-8) & $-\mathrm{C}\left(\mathrm{CH}_{3}\right)_{3}$ & $-\mathrm{CH}_{2}$ \\
Lupeol derivative 9 (L-9) & $-\mathrm{CCH}_{2} \mathrm{CH}_{3}$ & $-\mathrm{CH}_{2}$ \\
Lupeol derivative 10 (L-10) & $-\mathrm{COCH}_{3}$ & $-\mathrm{CH}_{2}$ \\
Lupeol derivative 11 (L-11) & $-\mathrm{OH}_{3}$ & $-\mathrm{COCH}_{3}$ \\
\hline
\end{tabular}

Table 2: Validation results of NA receptors PDB ID 2HU4 with cocrystal ligand oseltamivir

\begin{tabular}{|c|c|c|}
\hline Receptor & 3ERT & 3PP0 \\
\hline RMSD $(\AA)$ & 1.155 & 0.731 \\
\hline$\Delta \mathrm{G}(\mathrm{kcal} / \mathrm{mol})$ & -11.87 & -10.42 \\
\hline $\left.\mathrm{K}_{\mathrm{i}} \mu \mathrm{M}\right)$ & 0,00201 & 0.02297 \\
\hline \multirow[t]{16}{*}{ Amino acid residues } & 343-Met & 726-Leu \\
\hline & 346-Leu & 728-Ser \\
\hline & 347-Thr & 729-Gly \\
\hline & 350-Ala & 734-Val \\
\hline & 351-Asp & 751-Ala \\
\hline & 353-Glu & 753-Lys \\
\hline & 383-Trp & 774-Met \\
\hline & 384-Leu & 785-Leu \\
\hline & 387-Leu & 796-Leu \\
\hline & 394-Arg & 798-Thr \\
\hline & 428-Leu & 799-Gln \\
\hline & 521-Gly & 800-Leu \\
\hline & & 801-Met \\
\hline & & 852-Leu \\
\hline & & 863-Asp \\
\hline & & 864-Phe \\
\hline Number of hydrogen bonds & 2 & 0 \\
\hline \multirow[t]{3}{*}{ Grid box coordinate } & $X=-30.01$ & $X=-16.622$ \\
\hline & $Y=-1.913$ & $\mathrm{Y}=17.394$ \\
\hline & $\mathrm{Z}=24.207$ & $Z=-26.218$ \\
\hline Grid Box size $(\AA)$ & $60 \times 60 \times 60$ & $40 \times 40 \times 40$ \\
\hline
\end{tabular}

PDB: Protein data bank, RMSD: Root-mean-square deviation

Table 3: Docking results of lupeol derivatives at ER- $\alpha$ receptor (1)

\begin{tabular}{lllll}
\hline Ligand & L-0 & L-1 & L-2 & L-3 \\
\hline$\Delta \mathrm{G}(\mathrm{kcal} / \mathrm{mol})$ & -10.03 & -10.27 & -12.24 & -9.95 \\
$\mathrm{~K}_{\mathrm{i}}(\mu \mathrm{M})$ & 0.0441 & 0.0298 & 0.00107 & 0.05085 \\
Amino acid residues & 347-Thr & - & 347-Thr & - \\
& 351-Asp & - & 351-Asp & - \\
& 380-Glu & - & 380-Glu & - \\
& 383-Trp & 383-Trp & 383-Trp & 383-Trp \\
& - & - & - & - \\
& 522-Met & 522-Met & 522-Met & 522-Met \\
& - & $523-\mathrm{Glu}$ & - & 523-Glu \\
& 525-Leu & 525-Leu & 525-Leu & 525-Leu \\
& 526-Tyr & 526-Tyr & 526-Tyr & 526-Tyr \\
& 536-Leu & - & 536-Leu & - \\
& - & - & - & - \\
Number of hydrogen & 1 & 0 & 0 & 0 \\
bonds & & & & \\
\hline
\end{tabular}

receptor, lupeol-2 show the most negative $\Delta \mathrm{G}$ and the smallest $\mathrm{K}$. In other words, lupeol-2 has the highest affinity to ER- $\alpha$ receptor. While 
Table 4: Docking results of lupeol derivatives at ER- $\alpha$ receptor (2)

\begin{tabular}{lllll}
\hline Ligand & L-4 & L-5 & L-6 & L-7 \\
\hline$\Delta \mathrm{G}(\mathrm{kcal} / \mathrm{mol})$ & -10.23 & -11.81 & -10.53 & -11.05 \\
$\mathrm{~K}_{\mathrm{i}}(\mu \mathrm{M})$ & 0.0316 & 0.00222 & 0.01913 & 0.00797 \\
Amino acid residues & - & $347-\mathrm{Thr}$ & - & - \\
& - & $351-\mathrm{Asp}$ & - & $351-\mathrm{Asp}$ \\
& - & $380-\mathrm{Glu}$ & - & - \\
& 383-Trp & 383-Trp & 383-Trp & 383-Trp \\
& 519-Asn & - & $519-\mathrm{Asn}$ & - \\
& $522-\mathrm{Met}$ & $522-\mathrm{Met}$ & $522-\mathrm{Met}$ & $522-\mathrm{Met}$ \\
& $523-\mathrm{Glu}$ & - & $523-\mathrm{Glu}$ & - \\
& $525-\mathrm{Leu}$ & $525-\mathrm{Leu}$ & $525-\mathrm{Leu}$ & $525-\mathrm{Leu}$ \\
& $526-\mathrm{Tyr}$ & $526-\mathrm{Tyr}$ & $526-\mathrm{Tyr}$ & $526-\mathrm{Tyr}$ \\
& - & $536-\mathrm{Leu}$ & - & $536-\mathrm{Leu}$ \\
Number of & - & - & - & $539-\mathrm{Leu}$ \\
hydrogen bonds & 0 & 1 & 0 & 0
\end{tabular}

Table 5: Docking results of lupeol derivatives at ER- $\alpha$ receptor (3)

\begin{tabular}{lllll}
\hline Ligand & L-8 & L-9 & L-10 & L-11 \\
\hline$\Delta \mathrm{G}(\mathrm{kcal} / \mathrm{mol})$ & -10.81 & -10.43 & -10.24 & -10.57 \\
$\mathrm{~K}_{\mathrm{i}}(\mu \mathrm{M})$ & 0.01184 & 0.02258 & 0.03111 & 0.01789 \\
Amino acid residues & - & - & - & - \\
& - & - & - & 351-Asp \\
& - & - & - & 380-Glu \\
& 383-Trp & 383-Trp & 383-Trp & 383-Trp \\
& - & $519-\mathrm{Asn}$ & 519-Asn & - \\
& $522-\mathrm{Met}$ & $522-\mathrm{Met}$ & 522-Met & 522-Met \\
& - & $523-\mathrm{Glu}$ & 523-Glu & - \\
& $525-\mathrm{Leu}$ & $525-\mathrm{Leu}$ & $525-\mathrm{Leu}$ & 525-Leu \\
& $526-\mathrm{Tyr}$ & $526-\mathrm{Tyr}$ & $526-\mathrm{Tyr}$ & $526-\mathrm{Tyr}$ \\
& - & - & - & $536-\mathrm{Leu}$ \\
Number of hydrogen & - & - & - & - \\
bonds & 0 & 0 & 0 & 2 \\
\hline
\end{tabular}

Table 6: Docking results of lupeol derivatives at the HER2 receptor (1)

\begin{tabular}{|c|c|c|c|c|}
\hline Ligand & L-0 & L-1 & L-2 & L-3 \\
\hline$\Delta \mathrm{G}(\mathrm{kcal} / \mathrm{mol})$ & -9.25 & -9.11 & -6.86 & -8.32 \\
\hline $\mathrm{K}_{\mathrm{j}}(\mu \mathrm{M})$ & 0.16548 & 0.20972 & 9.36 & 0.78037 \\
\hline \multirow[t]{21}{*}{ Amino acid residues } & 726-Leu & 726-Leu & 726-Leu & 726-Leu \\
\hline & 728-Ser & 728-Ser & 728-Ser & 728-Ser \\
\hline & - & - & - & - \\
\hline & 734-Val & 734-Val & 734-Val & 734-Val \\
\hline & 751-Ala & 751-Ala & 751-Ala & 751-Ala \\
\hline & 753-Lys & 753-Lys & 753-Lys & 753-Lys \\
\hline & 783-Ser & 783-Ser & 783-Ser & 783-Ser \\
\hline & 785-Leu & 785-Leu & 785-Leu & 785-Leu \\
\hline & 796-Leu & 796-Leu & 796-Leu & 796-Leu \\
\hline & - & - & - & - \\
\hline & 798-Thr & 798-Thr & 798-Thr & 798-Thr \\
\hline & - & - & - & - \\
\hline & - & - & - & - \\
\hline & - & - & - & - \\
\hline & - & 805-Cys & 805-Cys & 805-Cys \\
\hline & 849-Arg & 849-Arg & 849-Arg & 849-Arg \\
\hline & 850-Asp & 850-Asp & 850-Asp & 850-Asp \\
\hline & 852-Leu & 852-Leu & 852-Leu & 852-Leu \\
\hline & 862-Thr & 862-Thr & 862-Thr & 862-Thr \\
\hline & 863-Asp & 863-Asp & 863-Asp & - \\
\hline & - & - & - & - \\
\hline $\begin{array}{l}\text { Number of hydrogen } \\
\text { bonds }\end{array}$ & 0 & 0 & 0 & 0 \\
\hline
\end{tabular}

Table 7: Docking results of lupeol derivatives at the HER2 receptor (2)

\begin{tabular}{|c|c|c|c|c|}
\hline Ligand & $L-4$ & L-5 & L-6 & L-7 \\
\hline$\Delta \mathrm{G}(\mathrm{kcal} / \mathrm{mol})$ & -9.63 & -7.42 & -8.23 & -5.92 \\
\hline $\mathrm{K}_{\mathrm{j}}(\mu \mathrm{M})$ & 0.08694 & 3.65 & 0.92474 & 46.1 \\
\hline \multirow[t]{21}{*}{ Amino acid residues } & 726-Leu & 726-Leu & 726-Leu & 726-Leu \\
\hline & - & - & - & - \\
\hline & - & - & - & - \\
\hline & 734-Val & 734-Val & 734-Val & 734-Val \\
\hline & 751-Ala & 751-Ala & 751-Ala & 751-Ala \\
\hline & 753-Lys & 753-Lys & 753-Lys & 753-Lys \\
\hline & 783-Ser & 783-Ser & 783-Ser & 783-Ser \\
\hline & 785-Leu & 785-Leu & 785-Leu & 785-Leu \\
\hline & 796-Leu & 796-Leu & 796-Leu & 796-Leu \\
\hline & - & - & - & - \\
\hline & 798-Thr & 798-Thr & 798-Thr & 798-Thr \\
\hline & - & - & 800-Leu & 800-Leu \\
\hline & - & - & 801-Met & 801-Met \\
\hline & 804-Gly & 804-Gly & 804-Gly & 804-Gly \\
\hline & 805-Cys & 805-Cys & 805-Cys & 805-Cys \\
\hline & 849-Arg & 849-Arg & - & - \\
\hline & - & - & - & - \\
\hline & 852-Leu & 852-Leu & 852-Leu & 852-Leu \\
\hline & 862-Thr & 862-Thr & 862-Thr & 862-Thr \\
\hline & 863-Asp & 863-Asp & 863-Asp & 863-Asp \\
\hline & - & - & 864-Phe & 864-Phe \\
\hline $\begin{array}{l}\text { Number of hydrogen } \\
\text { bonds }\end{array}$ & 0 & 0 & 0 & 0 \\
\hline
\end{tabular}

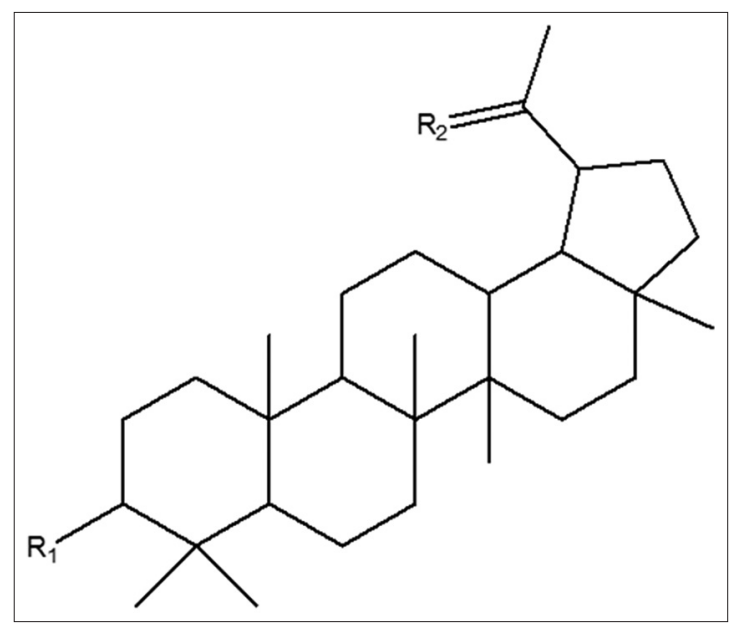

Fig. 1: Structure of lupeol [6]

in the HER2 receptor, the most negative $\Delta \mathrm{G}$ and the smallest $\mathrm{K}_{\mathrm{i}}$ are indicated by lupeol-4.

The comparison of amino acid residues and the number of hydrogen bonds between the redocking results of the cocrystal ligand of each receptor with lupeol and the highest affinity derivative were performed to analyze the similarities and differences types of interactions between each ligand [25]. The comparison for the ER- $\alpha$ receptor as shown in Table 9 shows that 4-hydroxytamoxifen with lupeol-0 and lupeol-2 have considerable differences in amino acid residues. . Interestingly, the affinity indicated by 4-hydroxytamoxifen is still higher than lupeol-0, but lower than lupeol-2. The $\mathrm{K}_{\mathrm{i}}$ score of lupeol-2 itself almost half from the $\mathrm{K}_{\mathrm{i}}$ score of 4-hydroxytamoxifen, indicating the lupeol-2 affinity that is almost two-fold than 4-hydroxytamoxifen. These results indicate that modification of amino groups at the position of $C$ number 3 can increase the affinity of lupeol against ER- $\alpha$ receptor.

Whether lupeol-0 and lupeol-2 have similar activity with 4-hydroxytamoxifen as an ER- $\alpha$ inhibitor or not is still unknown. However, amino acid residues shown by lupeol-0 and lupeol-2 have 
very little in common with amino acid residues of 4-hydroxytamoxifen ( 3 out of 12). These results indicated that although lupeol- 2 has a higher affinity than 4-hydroxytamoxifen toward ER- $\alpha$, it is likely that lupeol-2 does not exhibit ER- $\alpha$ inhibitory activity as possessed by 4-hydroxytamoxifen. Further observation of the docking results shown in Fig. 3 shows the considerable position difference between 4-hydroxytamoxifen with lupeol-0 and lupeol-2.
The comparison for HER2 receptor as shown in Table 10 shows that amino acid residues between TAK- 285 with lupeol- 0 and lupeol- 4 are not much different. In contrast to ER- $\alpha$ receptor, both lupeol-0 and lupeol-4 have lower affinity than TAK-285. However, the affinity of lupeol-4 is still higher than lupeol-0. The $\mathrm{K}_{\mathrm{i}}$ score of lupeol-4 itself is almost half of the $\mathrm{K}_{\mathrm{i}}$ score lupeol-0, but almost 4 times greater than the $\mathrm{K}_{\mathrm{i}}$ score of TAK-285. These results indicate that the modification of ethyl

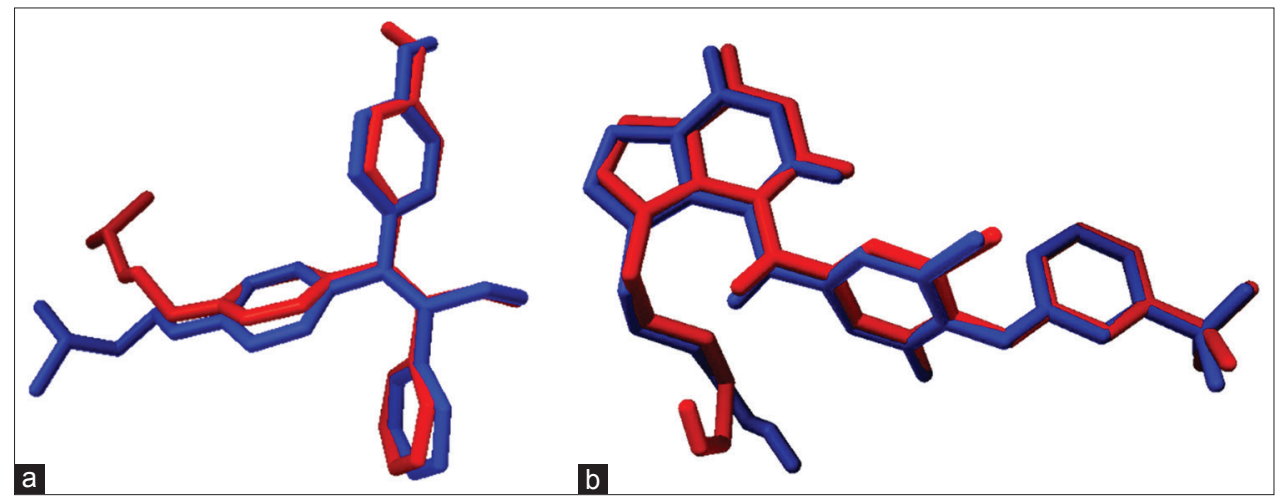

Fig. 2: Overlay of redocking (red) and crystallography (blue) ligand position; including 4-hydroxytamoxifen with root-mean-square deviation (RMSD): 1.155 ̊ (a) and TAK-285 with RMSD: 0.731Å (b)

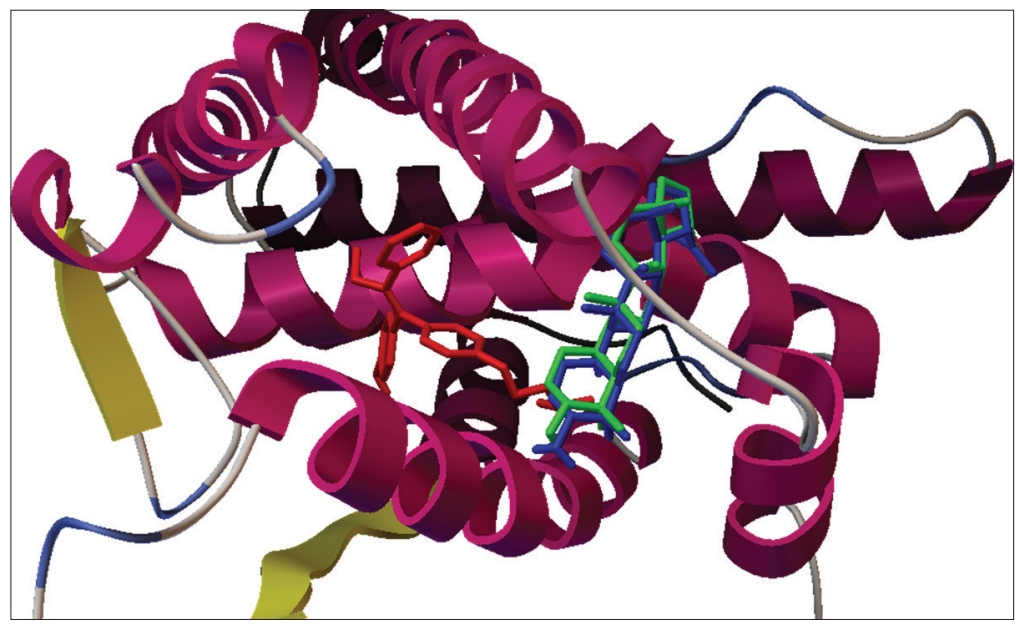

Fig. 3: Comparison of redocking result from 4-hydroxytamoxifen position (red) with docking result from lupeol-0 (blue) and lupeol-2 (green)

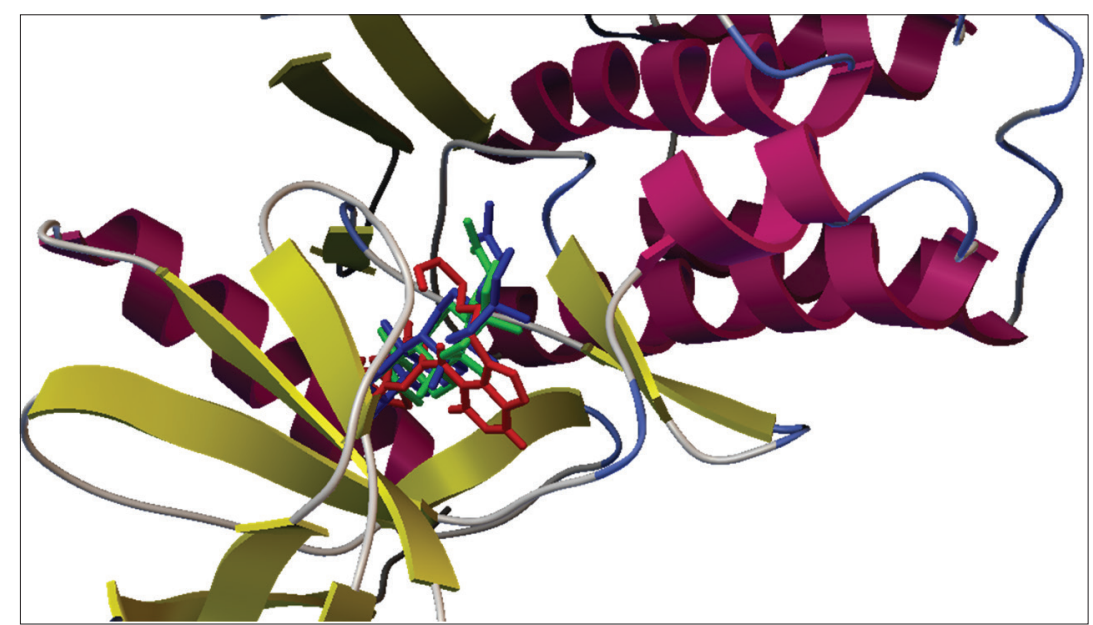

Fig. 4: Comparison of redocking result from TAK-285 position (red) with docking result from lupeol-0 (blue) and lupeol-4 (green) 
Table 8: Docking results of lupeol derivatives at the HER2 receptor (3)

\begin{tabular}{|c|c|c|c|c|}
\hline Ligand & L-8 & L-9 & L-10 & L-11 \\
\hline$\Delta \mathrm{G}(\mathrm{kcal} / \mathrm{mol})$ & -1.18 & -8.19 & -9.33 & -8.22 \\
\hline $\mathrm{K}_{\mathrm{i}}(\mu \mathrm{M})$ & 137080 & 0.99935 & 0.14539 & 0.94931 \\
\hline \multirow[t]{21}{*}{ Amino acid residues } & 726-Leu & 726-Leu & 726-Leu & 726-Leu \\
\hline & 728-Ser & - & - & - \\
\hline & 729-Gly & - & - & - \\
\hline & 734-Val & 734-Val & 734-Val & 734-Val \\
\hline & 751-Ala & 751-Ala & 751-Ala & 751-Ala \\
\hline & 753-Lys & 753-Lys & 753-Lys & 753-Lys \\
\hline & 783-Ser & 783-Ser & 783-Ser & 783-Ser \\
\hline & 785-Leu & 785-Leu & 785-Leu & - \\
\hline & 796-Leu & 796-Leu & 796-Leu & 796-Leu \\
\hline & 797-Val & 797-Val & - & - \\
\hline & 798-Thr & 798-Thr & 798-Thr & 798-Thr \\
\hline & - & - & - & - \\
\hline & - & - & - & - \\
\hline & - & - & 804-Gly & - \\
\hline & - & 805-Cys & 805-Cys & 805-Cys \\
\hline & - & 849-Arg & 849-Arg & 849-Arg \\
\hline & - & - & - & - \\
\hline & 852-Leu & 852-Leu & 852-Leu & 852-Leu \\
\hline & 862-Thr & 862-Thr & 862-Thr & 862-Thr \\
\hline & 863-Asp & 863-Asp & 863-Asp & - \\
\hline & 864-Phe & - & - & - \\
\hline $\begin{array}{l}\text { Number of } \\
\text { hydrogen bonds }\end{array}$ & 0 & 0 & 0 & 0 \\
\hline
\end{tabular}

Table 9: Comparison of redocking results of 4-hydroxytamoxifen with docking result of lupeol-0 and lupeol-2 toward ER- $\alpha$

\begin{tabular}{|c|c|c|c|}
\hline Ligand & 4-hydroxytamoxifen & L-0 & L-2 \\
\hline$\Delta \mathrm{G}(\mathrm{kcal} / \mathrm{mol})$ & -11.87 & -10.03 & -12.24 \\
\hline $\mathrm{K}_{\mathrm{i}}(\mu \mathrm{M})$ & 0.00201 & 0.0441 & 0.00107 \\
\hline \multirow[t]{17}{*}{ Amino acid residues } & 343-Met & - & - \\
\hline & 346-Leu & - & - \\
\hline & 347-Thr & 347-Thr & 347-Thr \\
\hline & 350-Ala & - & - \\
\hline & 351-Asp & 351-Asp & 351-Asp \\
\hline & 353-Glu & - & - \\
\hline & - & 380-Glu & 380-Glu \\
\hline & 383-Trp & 383-Trp & 383-Trp \\
\hline & 384-Leu & - & - \\
\hline & 387-Leu & - & - \\
\hline & 394-Arg & - & - \\
\hline & 428-Leu & - & - \\
\hline & 521-Gly & - & - \\
\hline & - & 522-Met & 522-Met \\
\hline & - & 525-Leu & 525-Leu \\
\hline & - & 526-Tyr & 526-Tyr \\
\hline & - & 536-Leu & 536-Leu \\
\hline $\begin{array}{l}\text { Number of } \\
\text { hydrogen bonds }\end{array}$ & 2 & 1 & 0 \\
\hline
\end{tabular}

groups at the position of $\mathrm{C}$ number 3 can multiply the affinity of lupeol toward HER2 receptor.

In contrast to ER- $\alpha$ receptor, the similarity of amino acid residues toward HER2 receptor represents a much greater number, even more than half of amino acid residues in TAK-285 ( 9 out of 16) also present in both lupeol-0 and lupeol-4. Regardless of the lower affinity, there is a great possibility that lupeol-0 especially lupeol-4 have similar HER2 inhibitory activity with TAK-285. Further observation of the docking results shown in Fig. 4 shows the similarity of binding positions between TAK-285 with lupeol-0 and lupeol-4.
Table 10: Comparison of redocking results of TAK-285 with docking result of lupeol-0 and lupeol-2 toward HER2

\begin{tabular}{|c|c|c|c|}
\hline Ligand & TAK-285 & L-0 & L-4 \\
\hline$\Delta \mathrm{G}(\mathrm{kcal} / \mathrm{mol})$ & -10.42 & -9.25 & -9.63 \\
\hline $\left.\mathrm{K}_{\mathrm{i}} \mu \mathrm{M}\right)$ & 0.02297 & 0.16548 & 0.08694 \\
\hline \multirow[t]{22}{*}{ Amino acid residues } & 726-Leu & 726-Leu & 726-Leu \\
\hline & 728-Ser & 728-Ser & - \\
\hline & 729-Gly & - & - \\
\hline & 734-Val & 734-Val & 734-Val \\
\hline & 751-Ala & 751-Ala & 751-Ala \\
\hline & 753-Lys & 753-Lys & 753-Lys \\
\hline & 774-Met & - & - \\
\hline & - & 783-Ser & 783-Ser \\
\hline & 785-Leu & 785-Leu & 785-Leu \\
\hline & 796-Leu & 796-Leu & 796-Leu \\
\hline & 798-Thr & 798-Thr & 798-Thr \\
\hline & 799-Gln & - & - \\
\hline & 800-Leu & - & - \\
\hline & 801-Met & - & - \\
\hline & - & - & 804-Gly \\
\hline & - & - & 805-Cys \\
\hline & - & 849-Arg & 849-Arg \\
\hline & - & 850-Asn & - \\
\hline & 852-Leu & 852-Leu & 852-Leu \\
\hline & - & 862-Thr & 862-Thr \\
\hline & 863-Asp & 863-Asp & 863-Asp \\
\hline & 864-Phe & - & - \\
\hline $\begin{array}{l}\text { Number of hydrogen } \\
\text { bonds }\end{array}$ & 0 & 0 & 0 \\
\hline
\end{tabular}

\section{CONCLUSION}

The presents study was successfully found the optimal optimization of lupeol chemical structure as the ER- $\alpha$ and HER2 inhibitors, even yielding interesting results where the activity of lupeol derivatives is more likely as HER2 than ER- $\alpha$ inhibitor. Although the resulting affinity is still lower than comparative ligands, the potential indicated by lupeol derivatives, especially lupeol- 4 which modified by the addition of ethyl group at the position of $\mathrm{C}$ number 3 as HER2 inhibitor is still promising. Further modification of atom $\mathrm{C}$ number 3 with other more lipophilic groups has the potential to increase the affinity of lupeol derivatives even further. Thus, the study clearly shows the promising potential for lupeol derivatives to be developed as a HER2 inhibitor in HER2-positive breast cancer therapy.

\section{ACKNOWLEDGMENT}

We thank the Rector of Muhammadiyah University of Palangkaraya, for providing assistance in the form of funding for this research. We also thank the Head of the Computation laboratory Muhammadiyah University of Palangkaraya, for providing Computer Laboratory Facility to carry out this research work.

\section{CONFLICT OF INTEREST}

All authors are declared, there is no conflict of interest.

\section{REFERENCES}

1. Sutomo S, Wahyuono S, Setyowati EP, Rianto S, Yuswanto A. Antioxidant activity assay of extracts and active fractions of kasturi fruit (Mangifera casturi Kosterm.) using 1,1-diphenyl-2-picrylhydrazyl method. J Nat Prod 2014;7:124-30.

2. Sutomo S, Wahyuono S, Setyowati EP, Yuswanto A. Aktivitas isolat buah Mangifera casturi Kosterm. Sebagai imunomodulator secara in vitro. In: Proceeding of the National Seminar and Workshop Perkembangan Terkini Sains Farmasi dan Klinik V; 2015 Nov; Padang, West Sumatera; Indonesia. Universitas Andalas; 2015. p. 260-6. 
3. Fakhrudin N, Putri PS, Sutomo S, Wahyuono S. Anti-inflammatory activity of methanolic extract of Mangifera casturi in thioglycollateinduced leukocyte migration in mice. Trad Med J 2013;18:151-6.

4. Pardede A, Koketsu M. Antioxidant and antileukemic activity of chemical components from bark of Mangifera casturi. Comp Clin Pathol 2017;26:499-504.

5. Sutomo S, Arnida A, Yunus R, Wahyuono S, Setyowati EP, Riyanto S. Isolation and identification of active compound of ethylacetate fraction of kasturi (Mangifera casturi Konsterm.) fruit from south kalimantan Indonesia. Res J Pharm Biol Chem Sci 2017;8:249-54.

6. Sutomo S, Wahyuono S, Rianto S, Setyowati EP. Isolation and identification of active compound of n-hexane fraction from kasturi (Mangifera casturi Konsterm.) against antioxidant and immunomodulatory activity. J Biol Sci 2013;13:596-604

7. Aratanechemuge Y, Hibasami H, Sanpin K, Katsuzaki H, Imai K, Komiya K. Induction of apoptosis by lupeol isolated from mokumen (Gossampinus malabarica L. Merr) in human promyelotic leukemia HL-60 cells. Oncol Rep 2004;11:289-92.

8. Cmoch P, Pakulski Z, Swaczynova J, Strnad M. Synthesis of lupanetype saponins bearing mannosyl and 3,6-branched trimannosyl residues and their evaluation as anticancer agents. Carbohydr Res 2008;343:995-1003

9. Lambertini E, Lampronti I, Penolazzi L, Khan MT, Ather A, Giorgi G, et al. Expression of estrogen receptor alpha gene in breast cancer cells treated with transcription factor decoy is modulated by Bangladeshi natural plant extracts. Oncol Res 2005;15:69-79.

10. Saleem M. Lupeol, a novel anti-inflammatory and anti-cancer dietary triterpene. Cancer Lett 2009;285:109-15.

11. Yamamoto-Ibusuki M, Arnedos M, Andre F. Targeted therapies for ER+/HER2-metastatic breast cancer. BMC Med 2015;13:137.

12. Nakayama A, Takagi S, Yusa T, Yaguchi M, Hayashi A, Tamura T, et al. Antitumor activity of TAK-285, an investigational, non-Pgp substrate HER2/EGFR kinase inhibitor, in cultured tumor cells, mouse and rat xenograft tumors, and in an HER2-positive brain metastasis model. J Cancer 2013;4:557-65.

13. Kaserer T, Beck KR, Akram M, Odermatt A, Schuster D. Review: Pharmacophore models and pharmacophore-based virtual screening: Concepts and applications exemplified on hydroxysteroid dehydrogenases. Molecules 2015;20:22799-832.

14. Kroemer RT. Structure-based drug design: Docking and scoring. Curr Protein Pept Sci 2007:8:312-28.
15. Meng XY, Zhang HX, Mezei M, Cui M. Molecular docking: A powerful approach for structure-based drug discovery. Curr Comput Aided Drug Des 2011;7:146-57.

16. Chabib L, Awaluddin R, Ikawati Z, Martien R, Ismail H. Molecular docking, pharmacophore modelling, and ADME-toxicity prediction of curcumin analog compounds as inflammatory inhibitor on rheumatoid arthritis. Int J Pharm Pharm Sci 2017;9:16-21.

17. Cosconati S, Forli S, Perryman AL, Harris R, Goodsell DS, Olson AJ. Virtual screening with autodock: Theory and practice. Expert Opin Drug Discov 2010;5:597-607.

18. O'Boyle NM, Banck M, James CA, Morley C, Vandermeersch T, Hutchison GR. Open babel: An open chemical toolbox. J Cheminform 2011;3:33.

19. Morris GM, Huey R, Lindstrom W, Sanner MF, Belew RK, Goodsell DS, et al. AutoDock4 and AutoDockTools4: Automated docking with selective receptor flexibility. J Comput Chem 2009;30:2785-91.

20. Mansel R, Goyal A, Nestour EL, Masini-Etévé V, O’Connell K, Afimoxifene (4-OHT) Breast Pain Research Group, et al. A phase II trial of afimoxifene (4-hydroxytamoxifen gel) for cyclical mastalgia in premenopausal women. Breast Cancer Res Treat 2007;106:389-97.

21. Aertgeerts K, Skene R, Yano J, Sang BC, Zuo H, Snell G, et al. Structural analysis of the mechanism of inhibition and allosteric activation of the kinase domain of HER2 protein. J Biol Chem 2011;286:18756-65.

22. Pratama MR. Molecular Docking of Anticancer Agents: Artemisinin and Derivatives as HER2 Inhibitor. In: Mahdiyah D, editor. SMICHS: Proceeding of $1^{\text {st }}$ Sari Mulia International Conference on Health and Science; 2015 Dec; Banjarmasin, South Borneo, Indonesia. Sari Mulia Institute of Health Science; 2015. p. 155-68.

23. Bissantz C, Folkers G, Rognan D. Protein-based virtual screening of chemical databases 1. Evaluation of different docking/scoring combinations. J Med Chem 2000;43:4759-67.

24. Kontoyianni M, McClellan LM, Sokol GS. Evaluation of docking performance: Comparative data on docking algorithms. J Med Chem 2004;47:558-65.

25. Pratama MR, Gusdinar T. Between artemisinin and derivatives with neuraminidase: A docking study insight. Asian J Pharm Clin Res 2017;10:304-8.

26. Kim R, Skolnick J. Assesment of programs for ligand binding affinity prediction. J Comput Chem 2008;29:1316-31.

27. Miladiyah I, Jumina J, Haryana SM, Mustofa. In silico molecular docking of xanthone derivatives as cyclooxygenase-2 inhibitor agents. Int J Pharm Pharm Sci 2017;9:98-104 